\title{
Flexural behavior of fiber reinforced lightweight concrete
}

\author{
Xavier Infant Alex (Main and Corresponding Author) \\ Department of Civil Engineering, RVS College of Engineering \\ 4/563 Ramanamaharishi Nagar \\ Dindigul (India) \\ infantalex@gmail.com, infantalex1@outlook.com
}

\section{Kalidas Arunachalam}

Department of Civil Engineering, Thiagarajar College of Engineering

P614 Behind A.R Hospital

K.K. Nagar

Madurai (India)

vakarunachalam@gmail.com, karcivil@tce.edu

\author{
Manuscript Code: 1409 \\ Date of Acceptance/Reception: 02.12.2019/25.04.2019 \\ DOI: $10.7764 /$ RDLC.18.3.536
}

\begin{abstract}
In this research the flexural behavior of lightweight aggregate concrete with inclusion of steel and glass fiber was investigated. Pumice aggregate was used for the replacement of normal weight aggregate to reduce the density of concrete in order to achieve lightweight concrete. The methodology consisted of comparing the results of conventional reference concrete, plain. Light Weight Aggregate Concrete (LWAC) and fiber reinforced LWAC. The beams were produced with two types of fiber reinforced LWAC, plain LWAC and conventional concrete with similar compressive strength to allow for the comparison of structural performance of the beam. The fibers were added in the LWAC to reduce the brittleness of the concrete in order to increase the energy absorption capacity and to control the faster rate of crack development. In this research steel and glass fibers were added separately in three percentages of $0.5,1.0$ and 1.5 based on the weight of concrete. The hybrid combinations of steel and glass fibers were not adopted in this study. The beam specimen with $20 \%$ LWA and $0.5 \%$ steel fiber has the increase in load carrying capacity by $28 \%$ as compared to control beam. The ductility ratio of the same beam is $85 \%$ more than that of control specimen.
\end{abstract}

Keywords: Flexural behavior, Lightweight, steel fiber, glass fiber, density of concrete, brittleness of the concrete.

Introduction

High density concrete increases the dead loads of the building, which will increase the foundation loads of the building. In order to reduce the density of concrete lightweight aggregates were utilized to attain lightweight concrete. Lightweight concrete was used as a good fire resistant and sound insulation material. By using lightweight concrete, the sections of the building members were minimized thus decreasing the cost of the building (Duzgun et al., 2005; Nicolas et al., 2011; Topcu, 1997). Due to the lower modulus of elasticity of lightweight concrete, there will be adverse effect on the development and propagation of crack. However, recently by utilizing various additive the mechanical and strength characteristics of lightweight concrete may be improved. For the improvement of the structural performance of lightweight concrete, fibers of various types and proportions have been used. The significant role of fibers is to resist and delay the propagation of cracks increasing the flexural and fatigue characteristics of reinforced concrete (Lee HyunHo, 2007; Lim \& Oh, 1999). Nowadays the advantages of structural lightweight concrete have been numerous as compared to those of normal weight concrete (Dolby, 1995; Gao et al., 1997; Kayali et al., 2000; Swamy \& Lixian 1995). Furthermore, high strength lightweight concrete production is desirable for practical applications (Hoff \& Elimov, 1997). Due to this high strength, brittle failure is possible (Hsu \& Hsu, 1994; Webb, 1993). To resist this brittle failure, fiber inclusion is considered for improving ductility.

With the inclusion of steel fibers in lightweight concrete, its load carrying capacity is increased nearer to the strength of ordinary concrete. Further, it increases the tensile and flexural strength, strength against explosive effects, resistance to dynamic and sudden loading. It is also effective in controlling the crack and decreasing the crack width. By adding steel fibers in lightweight concrete, the ability of deformation is increased and economical solutions are achieved by decreasing the weight of the concrete (Mohammadi et al., 2008; Wafa \& Ashour, 1992). Steel fibers are still preferably used over macro-synthetic fibers due to its creep behavior which is the time-dependent strain that develops in concrete due to sustained stress (Pujadas et al, 2017). By the inclusion of fibers a comparative study was conducted to expose differences in terms of crack patterns and load-deflection behavior directly related with particularities of the pullout response (Pujadas et al., 2014; Blanco et al., 2015). By adding glass fibers in lightweight concrete, there would be an effective means of controlling shrinkage cracking. Glass fiber inclusion promotes multiple micro cracking thus reducing the crack width and improves the flexural performance and ductility of lightweight concrete. Introduction of glass fiber 
also controls the negative impacts of exposure to elevated temperatures (Faiz et al., 2002). The present investigation aims at studying the effect of pumice aggregate along with steel and glass fiber on structural behaviour of Fiber Reinforced Light Weight Concrete (FRLWC) in order to make it a viable structural material to be used in construction industry.

\section{Material and methods}

\section{Methodology}

In the present research, the mechanical and structural behaviour of FRLWC have to be assessed. The following methodology has been adopted in this research.

- To conduct the literature review on FRLWC.

- To determine the properties of the material used in FRLWC.

- To investigate the unit weight and compressive characteristics of FRLWC.

- To investigate flexural behaviour of FRLWC beams.

- Based on this experimental investigation, meaningful conclusions will be arrived at.

\section{Cement}

The cement used in this study for all the mixes was Ordinary Portland Cement with 53 grade, conforming IS 12269:2013. The compressive strength of cement mortar was found out as per IS 269-2015 as 29, 42 and $55 \mathrm{~N} / \mathrm{mm}^{2}$ at 3, 7, 28 days, respectively. The cement properties are shown in Table 1.

\begin{tabular}{lc}
\multicolumn{2}{c}{ Table 1. Properties of cement. Source: Self-Elaboration. } \\
\hline Properties & Experimental Value \\
\hline Standard Consistency & $33 \%$ \\
Specific Gravity & 3.15 \\
Initial Setting Time & $55 \mathrm{~min}$ \\
Final Setting Time & $380 \mathrm{~min}$ \\
\hline
\end{tabular}

\section{Fine aggregate}

Natural river sand conforming zone II as per IS 383:2016 was used as the fine aggregate. The sand was air-dried and sieved to remove any foreign particles prior to mixing. The specific gravity, fineness modulus and water absorption were determined and shown in Table 2.

\begin{tabular}{lc}
\multicolumn{2}{c}{ Table 2. Properties of fine aggregate. Source: Self-Elaboration. } \\
\hline Properties & Experimental Value \\
\hline Specific Gravity & 2.62 \\
Water Absorption & $0.33 \%$ \\
Fineness Modulus & 2.75 \\
\hline
\end{tabular}

\section{Coarse aggregate}

Crushed granite coarse aggregate of particle size $20 \mathrm{~mm}$ having angular shape and confirming to IS: 2386 - 2016 was used for this investigation. In all the mixes, lightweight pumice aggregate was used as the replacement of coarse aggregate. The pumice aggregate used was saturated surface dried to avoid the water absorption in all the mixes. The properties of coarse aggregate and pumice aggregate are shown in Table 3. 
Table 3. Properties of Coarse and pumice aggregate. Source: Self-Elaboration.

\begin{tabular}{|c|c|c|}
\hline Properties & Coarse aggregate & Pumice aggregate \\
\hline Specific Gravity & 2.78 & 0.79 \\
\hline Water Absorption (\%) & 0.67 & 37.6 \\
\hline Impact value (\%) & 16.6 & 34.2 \\
\hline Crushing value (\%) & 29.3 & 49.2 \\
\hline Fineness Modulus & 6.89 & 4.17 \\
\hline
\end{tabular}

\section{Steel fiber}

Hooked steel fiber commercially available in the local market was used as fiber in this investigation. The diameter of the steel wire was found to be $1000 \mu \mathrm{m}$ and relative density was 7.85. The tensile strength of steel fibers used was $600 \mathrm{~N} / \mathrm{mm}^{2}$. The aspect ratio of steel fiber used was 50 .

\section{Glass fiber}

The diameter of the glass fiber was found to be 8 to $15 \mu \mathrm{m}$ and relative density was 2.54 . The strength of glass fibers used ranged from $2000-4000 \mathrm{~N} / \mathrm{mm}^{2}$. The aspect ratio of glass fiber used was 800 . The properties of fibers and mix designation of various mixtures having the pumice and fibers are shown in Table 5 and 6, respectively.

Table 4. Properties of fibers. Source: Self-Elaboration

\begin{tabular}{cccccc}
\hline \multicolumn{7}{c}{ Table 4. Properties of fibers. Source: Self-Elaboration. } \\
\cline { 3 - 6 } Fiber Type & $\begin{array}{c}\text { Relative } \\
\text { Density }\end{array}$ & $\begin{array}{c}\text { Diameter } \\
\text { in } \mu \mathrm{m}\end{array}$ & $\begin{array}{c}\text { Tensile } \\
\text { strength in MPa }\end{array}$ & $\begin{array}{c}\text { Modulus of } \\
\text { In MPa }\end{array}$ & $\begin{array}{c}\text { Strain at failure } \\
\text { in \% }\end{array}$ \\
\hline $\begin{array}{c}\text { Steel } \\
\text { Glass }\end{array}$ & 7.8 & 1000 & 600 & 210000 & $0.5-3.5$ \\
\hline
\end{tabular}

\section{Mix designation}

The mix design of M40 grade concrete as per code IS 10262:2009 was done. Fifteen mixtures with varying percentages of lightweight aggregate, steel and glass fibers were used including control concrete. The normal weight aggregate was replaced with $20 \%$ and $40 \%$ of pumice lightweight aggregate, along with the inclusion of steel and glass fiber. The replacement with $20 \%$ and $40 \%$ of pumice aggregate without inclusion of fibers was taken as P1 and P2 concrete respectively. In this research steel and glass fibers were incorporated separately in three percentages of $0.5,1.0$ and 1.5 based on the weight of concrete. The mix designations for various mixtures are given in Table 5.

\begin{tabular}{|c|c|c|c|c|c|c|c|c|c|c|c|c|c|c|c|}
\hline \multirow[b]{2}{*}{$\begin{array}{c}\text { Mix } \\
\text { Designation }\end{array}$} & \multirow[b]{2}{*}{$\begin{array}{c}\text { Control } \\
\text { Concrete }\end{array}$} & \multirow[b]{2}{*}{ P1 } & \multirow[b]{2}{*}{ P2 } & \multicolumn{6}{|c|}{ Steel fibers } & \multicolumn{6}{|c|}{ Glass fibers } \\
\hline & & & & P1S1 & P1S2 & P1S3 & P2S1 & $\mathrm{P} 2 \mathrm{~S} 2$ & $\mathrm{P} 2 \mathrm{S3}$ & P1G1 & $\mathrm{P} 1 \mathrm{G} 2$ & $\mathrm{P} 1 \mathrm{G} 3$ & P2G1 & P2G2 & $\mathrm{P} 2 \mathrm{G} 3$ \\
\hline$\%$ of fibers & - & - & - & 0.5 & 1.0 & 1.5 & 0.5 & 1.0 & 1.5 & 0.5 & 1.0 & 1.5 & 0.5 & 1.0 & 1.5 \\
\hline $\begin{array}{l}\% \text { of } \\
\text { pumice } \\
\text { aggregate }\end{array}$ & - & 20 & 40 & 20 & 20 & 20 & 40 & 40 & 40 & 20 & 20 & 20 & 40 & 40 & 40 \\
\hline
\end{tabular}

\section{Casting procedure}

All the specimens for testing were prepared at room temperature. Pumice aggregates were moistened and allowed to absorb water for 5 minutes to reduce water absorption of lightweight aggregates. The moistened pumice aggregates were mixed with cement and river sand in a drum mixer. Next, fibers were added into the drum and allowed to rotate at high speed to avoid clustering of fibers. After proper mixing, proper compaction of concrete was done using vibrating needle. 


\section{Experimental Investigation}

In this research fifteen mixtures were cast to study the flexural behavior of fiber reinforced lightweight concrete, investigations were carried out on beam specimens for determining the ultimate load and load deflection characteristics. The beam dimension of $100 \mathrm{~mm}$ width, $150 \mathrm{~mm}$ depth and $1500 \mathrm{~mm}$ length was chosen for all mixes in this study. For the fabrication of structural beams, $8 \mathrm{~mm}$ and $12 \mathrm{~mm}$ diameters of reinforcement bars were used. Two numbers of $12 \mathrm{~mm} \varphi$ bars were used as tension reinforcement, two numbers of $8 \mathrm{~mm} \varphi$ bars were used as compression reinforcement and $8 \mathrm{~mm} \varphi 2$ legged stirrups at $80 \mathrm{~mm} c / c$ spacing were used as shear reinforcement. These specimens were cured in water and tested for ultimate load, deflections and failure characteristics under $1 / 3$ point loading in accordance to IS: $516-1999$. In this study two point loading were applied using loading frame with a capacity of $400 \mathrm{kN}$ at the rate of $5 \mathrm{kN}$ per minute. The beam test setup with reinforcement bars were shown in Figure 1 . The flexural behaviour of the beam inducing the formation of crack and ultimate failure are shown in Figure 2 to 4.

Figure 1. Beam test setup with reinforcement bars. Source: Self-Elaboration.

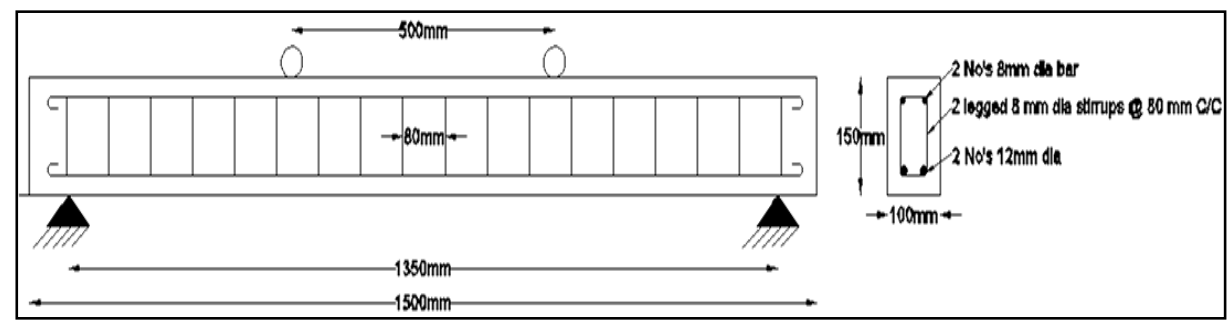

Figure 2. Formation of cracks in beam. Source: Self-Elaboration.

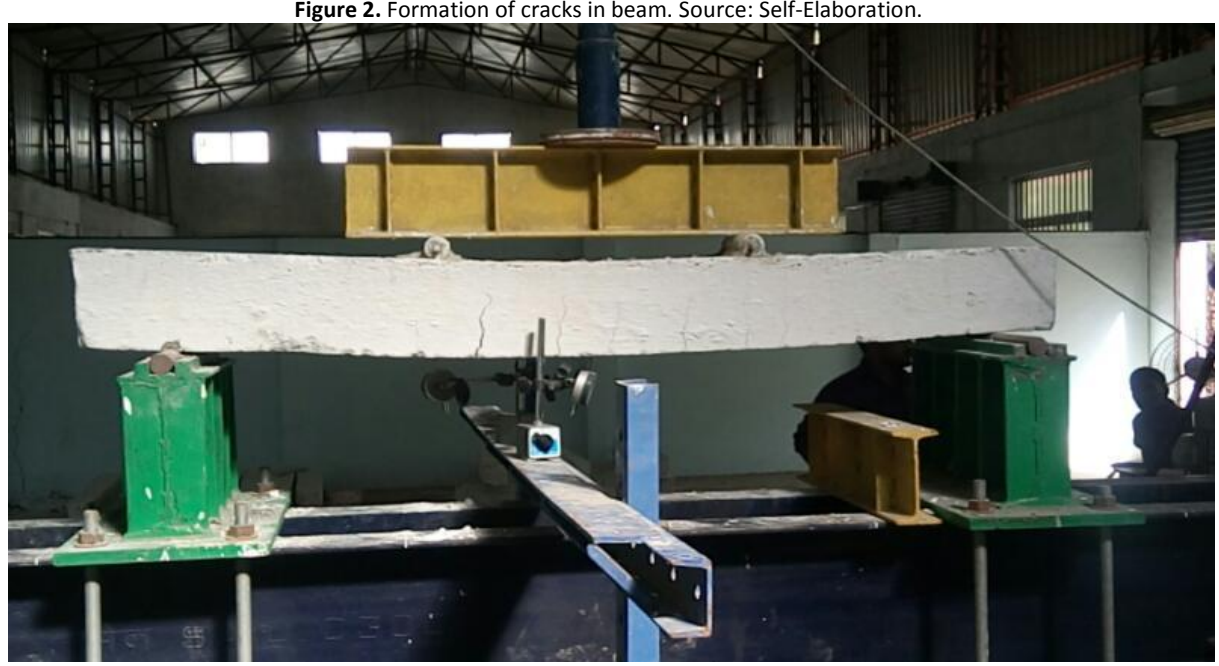

Figure 3. Flexural failure of beam. Source: Self-Elaboration.

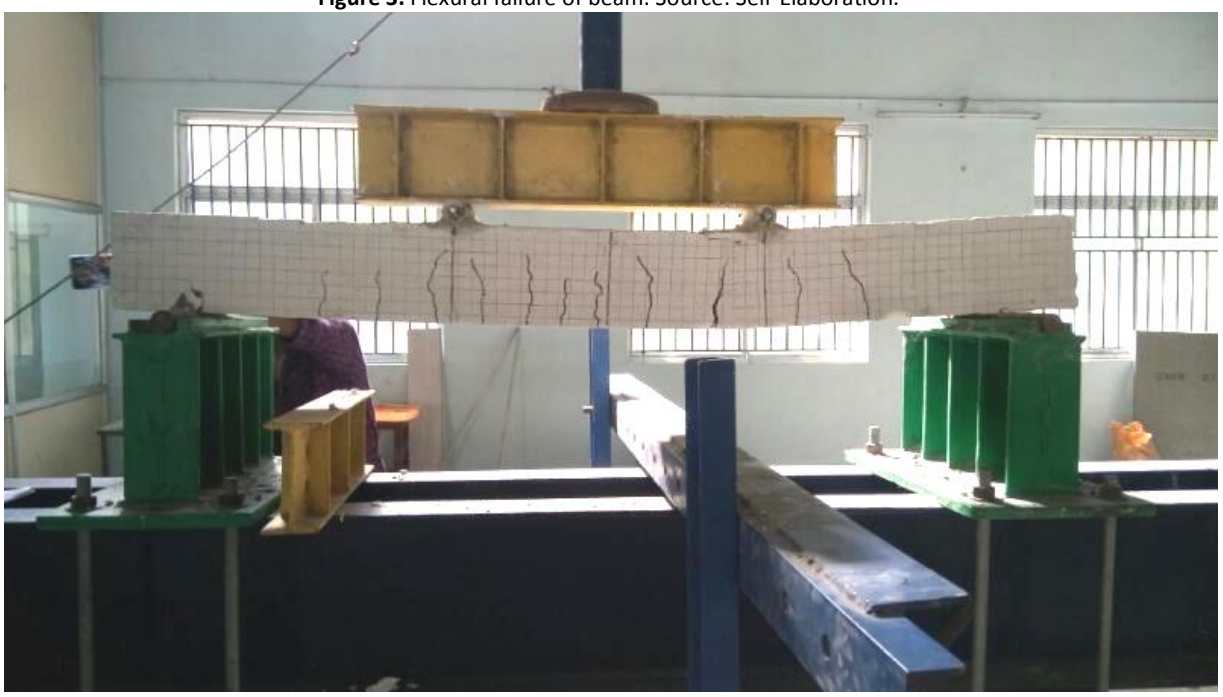




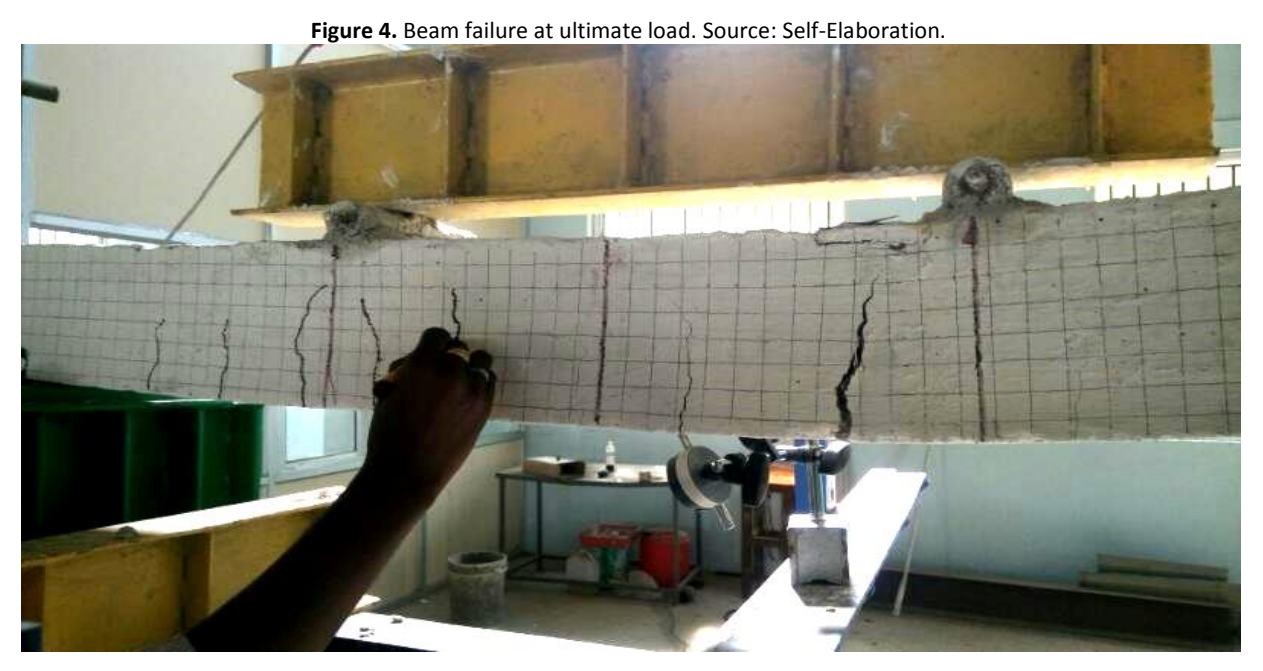

Results and discussion

\section{Unit weight of concrete}

The main purpose of this experiment is to minimize the unit weight of concrete. In order to minimize unit weight of concrete, the coarse aggregate was substituted with pumice aggregate by $20 \%$ and $40 \%$. A remarkable decrease in the unit weight was found when examined the unit weight of concrete. The control concrete had the unit weight of 2460 $\mathrm{kg} / \mathrm{m}^{3}$. The unit weight was decreased to $1985 \mathrm{~kg} / \mathrm{m}^{3}$ by replacing normal aggregate with $20 \%$ pumice aggregate (P1). In the same way the unit weight of concrete was further decreased to $1820 \mathrm{~kg} / \mathrm{m}^{3}$ by replacing with $40 \%$ pumice aggregate (P2). However the unit weight of concrete was increased by combining of steel and glass fibers. The mix P1 and P2 along with the inclusion of $0.5,1.0$ and $1.5 \%$ of steel fibers (P1S1, P1S2, P1S3, P2S1, P2S2, and P2S3) and glass fibers (P1G1, P1G2, P1G3, P2G1, P2G2, and P2G3) had the unit weight ranging from 1830 to $2200 \mathrm{~kg} / \mathrm{m}^{3}$. All the concrete mixes with and without fibers had the unit weight not as much the control concrete. Due to the higher specific gravity of fibers the increase in unit weight may occur. The unit weight for various mixes are shown in Figure 5 and Table 6.

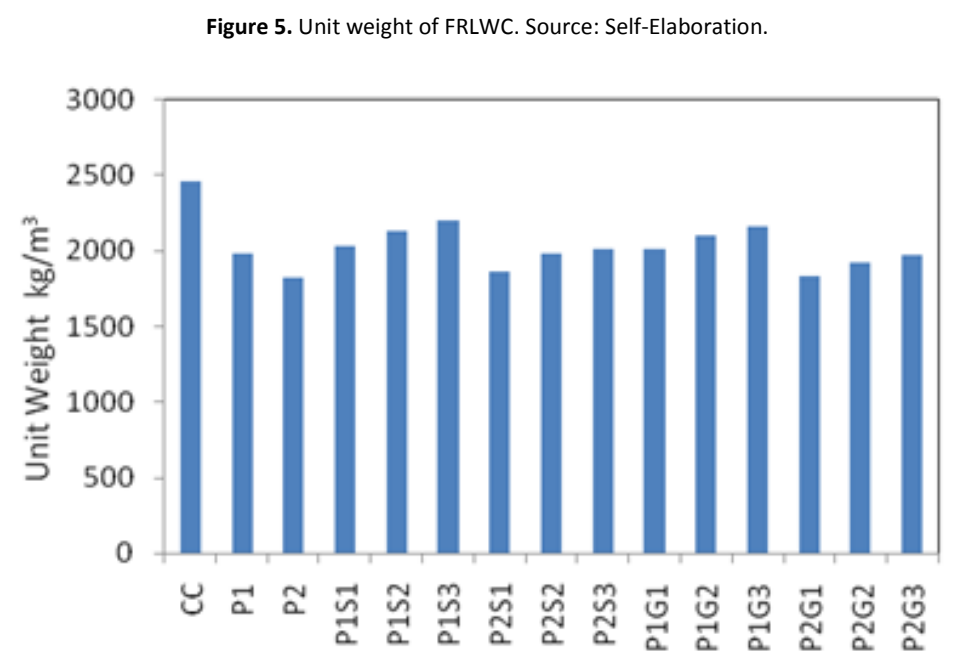

Mix Designation

\section{Compressive strength}

Since the concrete is good enough in compressive strength, the core compressive strength of concrete should not be reduced due to any kind of replacement in the concrete component. The compressive strength for various mixes are shown in Figure 6 and Table 6. From the obtained results, it is clearly understood that the presence of pumice aggregate decreases the compressive strength of concrete. 
Heavy weight aggregates are replaced by Pumice aggregates where their compressive strength were low and they cannot tolerate the desired compressive force. Even though lightweight concrete has been attained, it lost its core compressive strength. With a specific goal to build the compressive strength, steel and glass were added by different extents such as $0.5,1.0$ and 1.5 percentages. From the outcomes it was found that the P1 mix showed reduction in compressive strength by $29.9 \%$ and the $\mathrm{P} 2$ mix showed reduction in compressive strength by $41.6 \%$ when contrasted with the control concrete at 28 days. This reduction in compressive strength is because of the existence of cellular structure of light weight concrete in contrast to the normal weight concrete. The substitution of natural aggregate with $20 \%$ of pumice aggregate included with $0.5 \%$ of steel (P1S1) and glass fiber (P1G1) revealed increment in compressive strength by around $48 \%$ and $3.6 \%$, respectively when contrasted with $\mathrm{P} 1$ mix at 28 days.

The substitution of natural aggregate with $40 \%$ of pumice aggregate included with $0.5 \%$ of steel (P2S1) and glass fibers (P2G1) revealed increment in compressive strength by around $42 \%$ and $6.2 \%$ respectively when compared to the P2 mix at 28 days. From the outcome, it is understood that $0.5 \%$ steel fiber in P1 and P2 concrete mix (P1S1 and P2S1) enhanced the compressive strength of concrete by around $48 \%$ and $42 \%$ individually when compared to P1 and P2 mix. Incorporation of steel fibers in light weight concrete matrix over $0.5 \%$ prompts to deduction compressive strength. By including steel fibers further, the compressive strength appeared to be negligible because of the complication in scattering of the fibers and concrete was not being completely compacted (Gao et al, 1997).

On the other way, glass fibers had relatively lower impact on the compressive strength. It was noticed that P1S1 and P1S2 had the ideal compressive strength with the rate increment of $3.8 \%$ and $1.7 \%$ when contrasted to control concrete at 28 days. It is plainly noticeable from the results displayed that it is possible to deliver light weight concrete with compressive strength more desirable than control specimen by establishing steel fibers of $0.5 \%$ to $1 \%$ which helps in decreasing the inertial load (Campione et al., 2001).

Figure 6. Compressive strength of FRLWC. Source: Self-Elaboration.

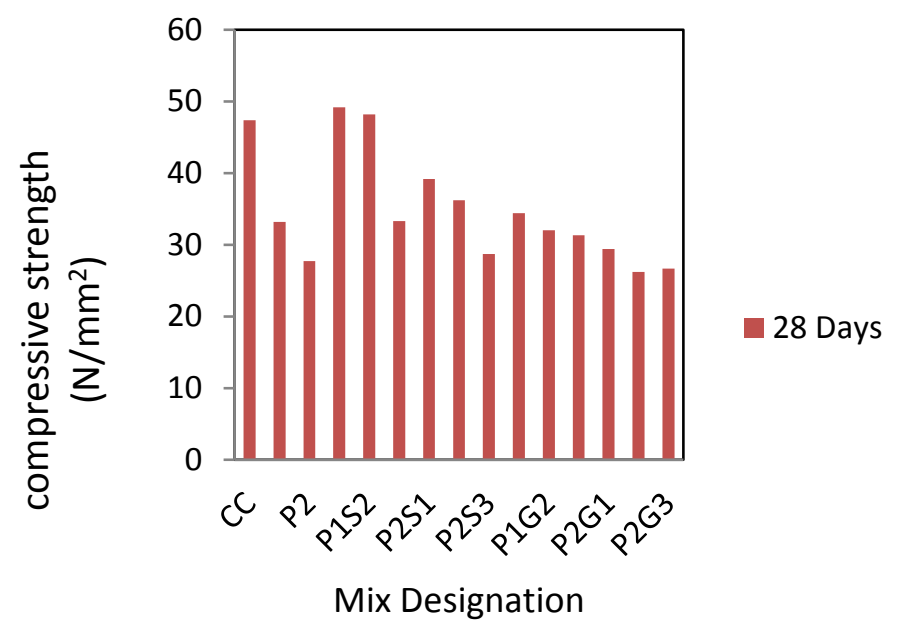

Table 6. Compressive strength and unit weight of various mixes. Source: Self-Elaboration.

\begin{tabular}{ccc}
\hline Mix Id & $\begin{array}{c}\text { Unit weight } \\
\left(\mathrm{kg} / \mathrm{m}^{3}\right)\end{array}$ & $\begin{array}{c}\text { Compressive } \\
\text { Strength } \\
(\mathrm{MPa})\end{array}$ \\
\hline CC & 2459 & 47.4 \\
P1 & 1985 & 33.2 \\
P2 & 1822 & 27.7 \\
P1S1 & 2030 & 49.2 \\
P1S2 & 2133 & 48.2 \\
P1S3 & 2207 & 33.3 \\
P2S1 & 1867 & 39.2 \\
P2S2 & 1985 & 36.2 \\
P2S3 & 2015 & 28.7 \\
P1G1 & 2015 & 34.4 \\
P1G2 & 2104 & 32 \\
P1G3 & 2163 & 31.3 \\
P2G1 & 1837 & 29.4 \\
P2G2 & 1926 & 26.2 \\
P2G3 & 1970 & 26.7 \\
\hline
\end{tabular}


Table 7. Load deflection reading for various mixes. Source: Self-Elaboration.

\begin{tabular}{cccccc}
\hline & \multicolumn{2}{c}{ Load and deflection at ultimate } \\
Specimen & Load and deflection at first crack & \multicolumn{2}{c}{ stage } & Ductility ratio \\
\cline { 2 - 5 } CC & 82.1 & 6.75 & Load $(\mathrm{kN})$ & Deflection $(\mathrm{mm})$ & 2.43 \\
P1 & 68.2 & 5.4 & 95 & 16.4 & 2.30 \\
P2 & 62.1 & 5.82 & 82 & 12.4 & 1.99 \\
P1S1 & 84.2 & 5.68 & 102 & 11.6 & 3.56 \\
P1S2 & 102.3 & 6.35 & 119 & 20.2 & 4.26 \\
P1S3 & 106.2 & 6.42 & 122 & 27.02 & 4.52 \\
P2S1 & 86.7 & 7.07 & 98 & 29 & 2.57 \\
P2S2 & 93.9 & 6.78 & 108 & 24.2 & 3.57 \\
P2S3 & 99.1 & 7.4 & 114 & 27 & 3.65 \\
P1G1 & 80.9 & 7.42 & 93 & 14.6 & 1.97 \\
P1G2 & 80.2 & 6.82 & 92 & 13.9 & 2.04 \\
P1G3 & 85.2 & 6.75 & 98 & 17.2 & 2.55 \\
P2G1 & 74.4 & 7.42 & 87 & 14.6 & 1.97 \\
P2G2 & 76.2 & 8.22 & 88 & 12.8 & 1.56 \\
P2G3 & 77.3 & 7.89 & 89 & 13.5 & 1.71 \\
\hline
\end{tabular}

Figure 7. Load deflection curve of LWC with steel fiber. Source: Self-Elaboration.

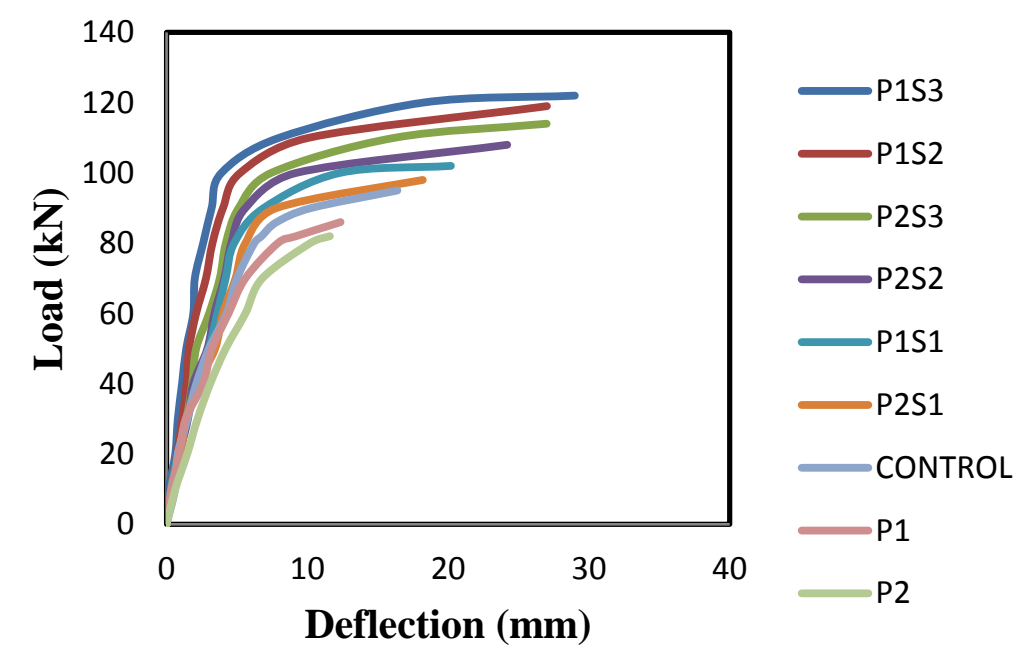

Figure 8. Load deflection curve of LWC with glass fiber. Source: Self-Elaboration.

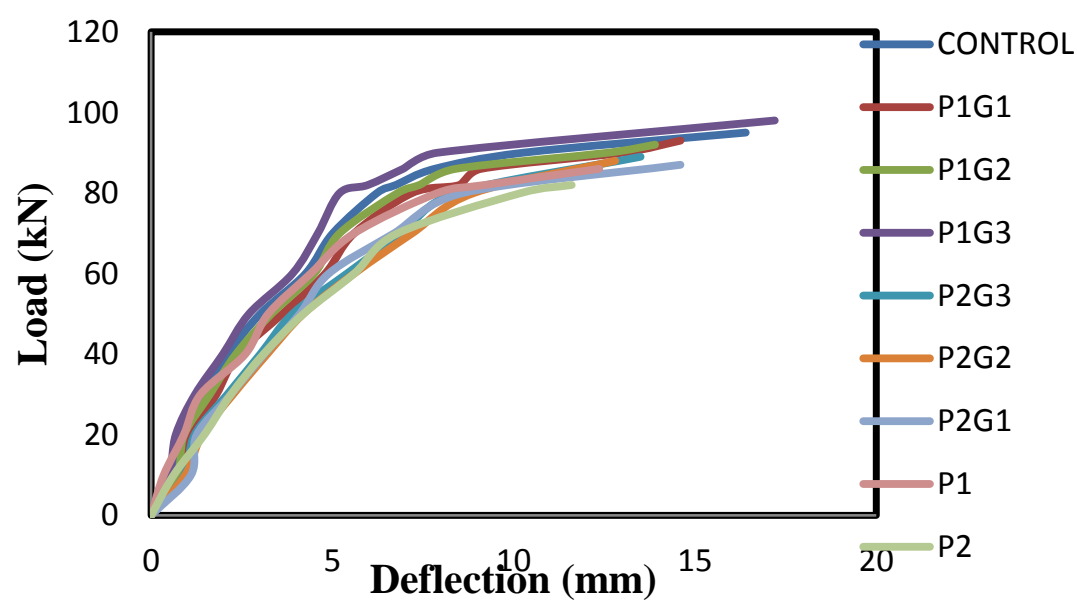


The load deflection parameter at first crack formation stage and ultimate stage for various mixes are tabulated in Table 7. The load deflection curve with incorporation of LWC and steel fiber is shown in Figure 7. The load deflection curve with incorporation of LWC and glass fiber is shown in Figure 8. Lightweight concrete beam accelerate the rate of crack propagation due to their lower elastic modulus. However, fibers are used as an additive in order to increase the ductility behavior of lightweight concrete. The fiber inclusion promotes multiple micro cracking thus reducing the crack width and improves the flexural post cracking behaviour and the energy absorption capacity of the lightweight concrete. The crack propagation of concrete beams starts when the strain in the tensile field exceeds concrete strain. When the load increases, the beam would undergo maximum bending moment and reaches a yield strain of reinforcement at certain level of load. The important influence of the fibers is to delay the crack propagation in the tensile area of the lightweight concrete beams. The ductility ratio values for various mixes are shown in Table 7. Ductility is the deformation ability beyond initial yield deformation without loss in strength. From the result, it is observed that the ductility ratio of P1S3 and P1G3 specimen is $85 \%$ and $5 \%$ more than that of control specimen respectively. The beam specimens P1S, P2S series and $\mathrm{P} 1 \mathrm{G} 3$ show a significant increase in post yield deflection when compared with control specimen. Similarly the beam specimens P1S, P2S series and P1G3 help to hold a peak load until a large deflection when compared with control specimen. The specimen P1S3 undergoes increase in load of $28 \%$ as compared to control specimen. The beam specimen with inclusion of steel fiber shows considerable improvement in the load carrying capacity as compared to the specimen with inclusion of glass fibers. During experimentation, it was observed that the specimen of P1S series allowed crack formation but the binding effect of steel fiber restricted its rate of growth. From the result it is observed that steel fiber carries the maximum flexural load due to the interior bond between the fiber and cement matrix. This interior bond delays the propagation of crack and sudden rupture of beam specimen which in turn increasing ductility behavior of steel fiber. On the other side, glass fiber has relatively lower effect on load deflection behavior of beam specimen. The lower effect of glass fiber on load deflection behavior is due to weaker bonding of glass fiber with the cement matrix as compared to steel fiber.

Fiber reinforced lightweight concrete mixes were prepared using lightweight coarse (pumice) aggregate, steel fiber and glass fiber. The mix P1 an P2 developed with $20 \%$ and $40 \%$ replacement of normal aggregate with pumice have the unit weight of $1985 \mathrm{~kg} / \mathrm{m}^{3}$ and $1820 \mathrm{~kg} / \mathrm{m}^{3}$ respectively. The mixes developed with the incorporation of glass and steel fibers have the unit weight ranging from $1830 \mathrm{~kg} / \mathrm{m}^{3}$ to $2200 \mathrm{~kg} / \mathrm{m}^{3}$. The unit weight of fiber reinforced lightweight concrete is lower compared to that of control concrete.

The compressive strength seems to increase with the inclusion of $0.5 \%$ of steel fibers in $\mathrm{P} 1$ mix with percentage increase of $3.8 \%$ as compared to control mix at 28 days. Inclusion of glass fiber has relatively lower effect on the compressive strength as compared to steel fiber.

The ductility of P1S3 and P1G3 beam specimen is $85 \%$ and $5 \%$ more than that of control specimen respectively. The beam specimens P1S1, P1S2, P1S3, P2S1, P2S1, P2S2, P2S3 and P1G3 show a significant increase in post yield deflection when compared with control specimen.

The beam specimens P1S1, P1S2, P1S3, P2S1, P2S1, P2S2, P2S3 and P1G3 help to hold a peak load until a large deflection when compared with control specimen. The beam specimen P1S3 undergoes increase in load of $28 \%$ as compared to control specimen.

From the results it is finally concluded that the loss of strength and ductility performance of LWAC can be compensated by the inclusion of fibers, without compromising much on the lightweight of the structure.

References

Blanco, A., Pujadas, P., De la Fuente, A., Cavalaro, S., \& Aguado, A. (2015). Assessment of the fibre orientation factor in SFRC slabs. Composites Part $B, 68,343-354$. https://www.academia.edu/17546417/Assessment_of_the_fibre_orientation_factor_in_SFRC_slabs

Campione, G., Miraglia, N., \& Papia, M. (2001). Mechanical properties of steel fiber reinforced lightweight concrete with pumice stone or expanded clay aggregates. Materials Structures, 34, 201-210. https://link.springer.com/article/10.1007/BF02480589

Duzgun, O.A., Gul, R., \& Aydın A.C. (2005). Effects of steel fiber on the mechanical properties of natural lightweight aggregate concrete. Materials Letters, 59, 3357-63. https://www.infona.pl/resource/bwmeta1.element.elsevier-78fbf5a8-7931-3d8f-879f 723adcdcddfb 
Dolby, P.G. (1995). Production and properties of lytag aggregate fully utilized. In: Holand et al., editors. Proceedings of the International Symposium on Structural Lightweight Aggregate Concrete 20-24 June 1995, Sandefjord, Norway. Oslo: The Norwegian Concrete Association, 326-335.

Faiz A Mirza., \& Parviz Souroushian. (2002). Effects of alkali resistant glass fiber reinforcement on crack and temperature resistance of lightweight concrete. Cement and Concrete Composites, 24, 223-227. https://www.sciencedirect.com/science/article/abs/pii/S0958946501000385

Gao, J., Sun, W., \& Morino, K. (1997). Mechanical properties of steel fiberreinforced, high-strength, lightweight concrete. Cement Concrete Composites, 19(4), 307-13. https://www.sciencedirect.com/science/article/abs/pii/S0958946597000231

Hoff, G.C., \& Elimov, R. (1997). The effect of air-entrainment on a pumped, high-strength concrete used in severe marine environment. In: Malhotra VM, editor. Durability of Concrete, ACI SP-17; V.1, 65-92.

Hsu, L.S., \& Hsu, C-T.T. (1994). Stress-strain behaviour of steel fiber highstrength concrete under compression. ACI Structural Journal, 91(4), 448-57. http://irc.nrc-cnrc.gc.ca/ircpubs

Kayali, O., \& Haque, M.N. (2000). Status of structural lightweight concrete in Australia as the new millennium dawns. Concrete Australia, 25(4), 2225. https://p2infohouse.org/ref/45/44659.pdf

Lee Hyun-Ho. (2007). Shear strength and behavior of steel fiber reinforced concrete columns under seismic loading. Engineering Structures, 29, 12531262. https://app.dimensions.ai/details/publication/pub.1020010246? and_facet_journal=jour.1053136

Lim, D.H., \& Oh, B.H. (1999). Experimental and theoretical investigation on the shear of steel fibre reinforced concrete beams. Engineering Structures, 21, 937-944. https://books.google.co.in/books?id=-oG4l_gJsi4C\&pg=PA278\&lpg=PA278\&dq=Lim,+D.H

Mohammadi, Y., Singh, S.P., \& Kaushik, S.K. (2008). Properties of steel fibrous concrete containing mixed fibers in fresh and hardened states. Construction Building Materials, 22, 956-965. https://www.sciencedirect.com/science/article/abs/pii/S0950061806003515

Nicolas, A.L., Mohammad, S., Mehrdad, M., \& Parviz, S. (2011). Mechanical properties of hybrid fiber reinforced lightweight aggregate concrete made with natural pumice. Construction Building Materials, 25, 2458-2464. https://www.academia.edu/4300079/ Mechanical_properties _of_hybrid_fiber_reinforced_lightweight_aggregate_concrete_made_with_natural_pumice

Pujadas, P., Blanco, A., Cavalaro, S., and Aguado, A. (2014). Plastic fibres as the only reinforcement for flat suspended slabs: Experimental investigation and numerical simulation. Construction Building Materials, 57, 92-104. https://www.atem.upc.edu/plastic-fibres-as-the-only-reinforcementfor-flat-suspended-slabs-experimental-investigation-and-numerical-simulation/

Pujadas, P., Blanco, A., Cavalaro, S., De la Fuente, A \& Aguado, A. (2017). Flexural post-cracking creep behaviour of macro-synthetic and steel fiber reinforced concrete. International RILEM Workshop on creep behaviour in cracked section of Fibre Reinforced Concrete, 77-87. https://link.springer.com/book/10.1007/978-94-024-1001-3

Swamy, R.N., \& Lixian, W. (1995). The ingredients for high performance in structural lightweight aggregate concrete. In: Holand et al., editors. Proceedings of the International Symposium on Structural Lightweight Aggregate Concrete 20-24 June 1995, Sandefjord, Norway. Oslo: The Norwegian Concrete Association, 628-639.

Topcu, I.B. (1997). Semi-lightweight concretes produced by volcanic slags. Cement Concrete Research, $27,15-21$.

Webb, J. (1993). High-strength concrete: economics, design and ductility. Concrete International, 15(1), 27-32. https://www.concrete.org/ publications/internationalconcrete abstractsportal/ $\mathrm{m} /$ details/id/4229

Wafa, F.F., \& Ashour, S.A. (1992). Mechanical properties of high-strength fiber reinforced concrete. ACl Materials Journal, 90(5), $449-455$. https://scholar.google.co.in/ scholar?q=.+Mechanical+properties+of+high-strength+fiber+reinforced+concrete. 